\title{
Teaching NeuroImages: Atrophy in epileptic encephalopathy
}

Ingo Helbig, MD, and Laura Adang, MD, PhD

Neurology ${ }^{\circledR}$ 2018;90:e442-e443. doi:10.1212/WNL.0000000000004884

\section{Correspondence}

Dr. Helbig

helbigi@email.chop.edu

Figure MRI of the brain

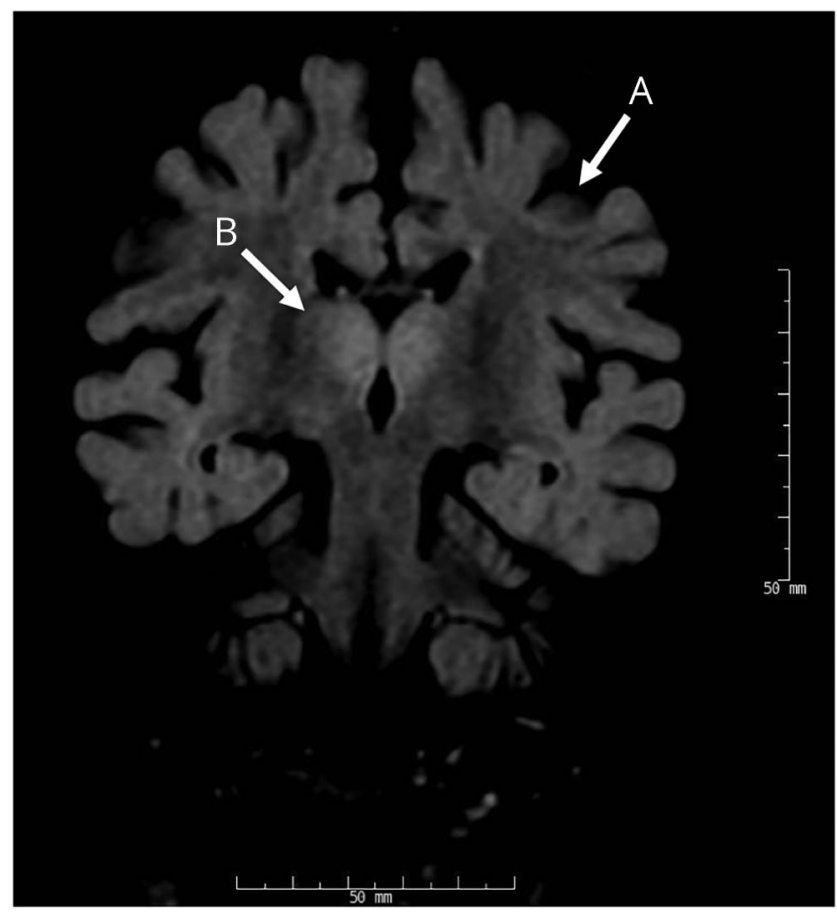

Brain MRI demonstrates diffuse atrophy (A) and bilateral and symmetrical T2/fluid-attenuated inversion recovery hyperintense signal intensity in the thalami (B). Prior MRI at the age of 1 and 5 months were unremarkable. Magnetic resonance spectroscopy at the age of 5 months and 3 years was unremarkable.

Neuroimaging in a 6-year-old girl with an unknown neurodegenerative disorder showed atrophy and bilateral thalamic T2/fluid-attenuated inversion recovery hyperintense signal intensity (figure). A mitochondrial or metabolic condition was suspected. Through a targeted gene panel, the patient was found to have a de novo KCNT1 mutation, a gene known to cause of a broad range of epileptic encephalopathies. ${ }^{1}$

Channelopathies may present with features suggesting neurodegenerative or neurometabolic disorders, or leukodystrophies. ${ }^{2}$ Epilepsies due to de novo mutations are more common by probably more than an order of magnitude and atypical presentations may be on the differential for unsolved neurodegenerative disorders.

\section{MORE ONLINE}

$\rightarrow$ Teaching slides:

links.lww.com/WNL/A187

From the Division of Neurology, The Children's Hospital of Philadelphia, PA.

Go to Neurology.org/N for full disclosures. Funding information and disclosures deemed relevant by the authors, if any, are provided at the end of the article. 


\section{Author contributions}

Ingo Helbig: study concept of design and acquisition of data. Laura Adang: study concept of design and critical revision of manuscript for intellectual content.

\section{Study funding}

No targeted funding reported.

\section{Disclosure}

The authors report no disclosures relevant to the manuscript. Go to Neurology.org/N for full disclosures.

\section{References}

1. Barcia G, Fleming MR, Deligniere A, et al. De novo gain-of-function KCNT1 channel mutations cause malignant migrating partial seizures of infancy. Nat Genet 2012;44:1255-1259.

2. Vanderver A, Simons C, Helman G, et al. Whole exome sequencing in patients with white matter abnormalities. Ann Neurol 2016;79:1031-1037. 


\section{Neurology}

\section{Teaching NeuroImages: Atrophy in epileptic encephalopathy Ingo Helbig and Laura Adang \\ Neurology 2018;90;e442-e443 \\ DOI 10.1212/WNL.0000000000004884}

This information is current as of January 29, 2018

\section{Updated Information \& Services}

\section{References}

Citations

Subspecialty Collections

Permissions \& Licensing

Reprints including high resolution figures, can be found at: http://n.neurology.org/content/90/5/e442.full

This article cites 2 articles, 0 of which you can access for free at: http://n.neurology.org/content/90/5/e442.full\#ref-list-1

This article has been cited by 1 HighWire-hosted articles: http://n.neurology.org/content/90/5/e442.full\#\#otherarticles

This article, along with others on similar topics, appears in the following collection(s):

All Epilepsy/Seizures

http://n.neurology.org/cgi/collection/all_epilepsy_seizures

Infantile spasms

http://n.neurology.org/cgi/collection/infantile_spasms

Ion channel gene defects

http://n.neurology.org/cgi/collection/ion_channel_gene_defects Status epilepticus

http://n.neurology.org/cgi/collection/status_epilepticus

Information about reproducing this article in parts (figures,tables) or in its entirety can be found online at:

http://www.neurology.org/about/about_the_journal\#permissions

Information about ordering reprints can be found online:

http://n.neurology.org/subscribers/advertise

Neurology ${ }^{\circledR}$ is the official journal of the American Academy of Neurology. Published continuously since 1951, it is now a weekly with 48 issues per year. Copyright () 2018 American Academy of Neurology. All rights reserved. Print ISSN: 0028-3878. Online ISSN: 1526-632X.

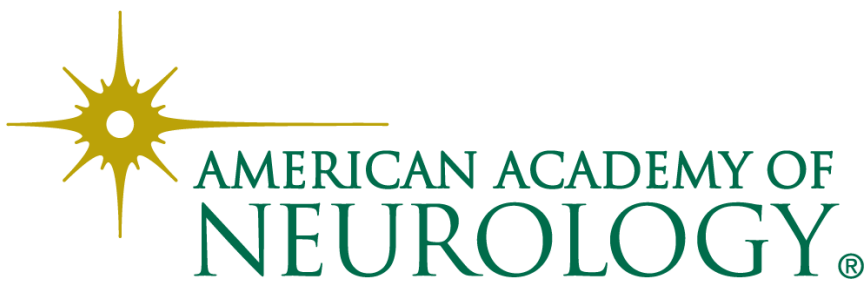

